\title{
NOTE ON \\ QUOTATIONS AND CITATIONS
}

$\mathbf{0}$ ASSAGES quoted from The Canterbury Tales have been compared with The Text of the Canterbury Tales, ed. J. M. Manly and Edith Rickert, 8 vols. (Chicago: Univ. of Chicago Press, 1940). Passages quoted from Chaucer's other works have been compared with texts offered in The Works of Geoffrey Chaucer, ed. F. N. Robinson, 2nd ed. (Cambridge, Mass.: Houghton Mifflin, 1957). However, I have consulted textual notes and compared other editions, and have sometimes preferred the reading of another editor, usually explaining my preference in a footnote. Punctuation is my own. Numbered line references conform to the Robinson edition.

The Middle English spelling is normalized: I have as best I could removed non-functional old spellings according to the principles stated in The Canterbury Tales: $A$ Selection, ed. Donald R. Howard with James Dean, Signet Classic Poetry Series (New York: New American Library, 1969), pp. xxxix$\mathrm{xl}$. My reason for quoting Chaucer this way is my conviction that his infinitely supple language is a living one too vibrant to be valued for its quaint appearance on a page. I have been fretfully mindful of Chaucer's warning in Troilus, V. 17931798 against miswriting or mismetering his poetry; but I have been mindful too of the "grete diversitee," greater than he could have imagined, in English speech and writing especially in the century after his death when extant manuscripts were copied-and mindful of his final and most earnest prayer, that his poetry be understood. 